\title{
Flipside of the Coin: Iron Deficiency and Colorectal Cancer
}

\author{
Aysegül Aksan ${ }^{1,2,3 \dagger}$, Karima Farrag ${ }^{3,4 \dagger}$, Sami Aksan ${ }^{3,4}$, Oliver Schroeder ${ }^{3,4 \dagger}$ and \\ Jürgen Stein ${ }^{2,3,4 *}$
}

${ }^{1}$ Institute of Nutritional Science, Justus-Liebig University, Giessen, Germany, ${ }^{2}$ Institute of Pharmaceutical Chemistry, Goethe University, Frankfurt, Germany, ${ }^{3}$ Interdisziplinäres Crohn Colitis Centrum, Rhein-Main, Frankfurt, Germany, ${ }^{4}$ DGD Kliniken Sachsenhausen, Frankfurt, Germany

\section{OPEN ACCESS}

Edited by:

Paola Zacchi,

University of Trieste, Italy

Reviewed by:

Tiziana Schioppa,

University of Brescia, Italy

Tariq lqbal,

Queen Elizabeth Hospital Birmingham,

United Kingdom

*Correspondence:

Jürgen Stein

j.stein@em.uni-frankfurt.de orcid.org/0000-0003-3558-3341

TORCID:

Aysegül Aksan orcid.org/0000-0003-2819-3484

Karima Farrag

orcid.org/0000-0002-5071-7072

Oliver Schroeder

orcid.org/0000-0002-3182-8308

Specialty section:

This article was submitted to

Cancer Immunity and Immunotherapy,

a section of the journal

Frontiers in Immunology

Received: 30 November 2020

Accepted: 18 February 2021

Published: 11 March 2021

Citation:

Aksan A, Farrag K, Aksan S,

Schroeder O and Stein J (2021)

Flipside of the Coin: Iron Deficiency and Colorectal Cancer.

Front. Immunol. 12:635899 doi: 10.3389/fimmu.2021.635899
Iron deficiency, with or without anemia, is the most frequent hematological manifestation in individuals with cancer, and is especially common in patients with colorectal cancer. Iron is a vital micronutrient that plays an essential role in many biological functions, in the context of which it has been found to be intimately linked to cancer biology. To date, however, whereas a large number of studies have comprehensively investigated and reviewed the effects of excess iron on cancer initiation and progression, potential interrelations of iron deficiency with cancer have been largely neglected and are not well-defined. Emerging evidence indicates that reduced iron intake and low systemic iron levels are associated with the pathogenesis of colorectal cancer, suggesting that optimal iron intake must be carefully balanced to avoid both iron deficiency and iron excess. Since iron is vital in the maintenance of immunological functions, insufficient iron availability may enhance oncogenicity by impairing immunosurveillance for neoplastic changes and potentially altering the tumor immune microenvironment. Data from clinical studies support these concepts, showing that iron deficiency is associated with inferior outcomes and reduced response to therapy in patients with colorectal cancer. Here, we elucidate cancer-related effects of iron deficiency, examine preclinical and clinical evidence of its role in tumorigenesis, cancer progression and treatment response. and highlight the importance of adequate iron supplementation to limit these outcomes.

Keywords: iron deficiency, iron deficiency anemia, colorectal cancer, immune host defense, intravenous iron therapy

\section{INTRODUCTION}

Colorectal cancer (CRC) is the third most deadly and fourth most diagnosed cancer worldwide, and its incidence is steadily rising in developing nations (1). Both genetic characteristics and environmental factors play a role in intestinal carcinogenesis $(2,3)$. Alongside other well-established contributors, iron has recently emerged as a possible culprit in colorectal carcinogenicity (4). Published data support the hypothesis that excess oral iron intake is associated with an increased risk of CRC (5-8).

Iron is a vital micronutrient that has an essential role in many biological functions, in the context of which it has been found to be intimately linked to cancer biology $(4,9,10)$. The trace element is required for energy production and intermediary metabolic actions as a catalyzer for REDOX-mediating enzymes. Proteins may bind directly to iron or contain iron in the form of heme or iron-sulfur clusters (11). Iron generates oxygen free radicals, which may in turn cause 
iron-induced apoptosis or ferroptosis. Furthermore, these ironoxygen complexes are complicit in promoting mutagenicity and malignant transformation. Having undergone transformation, malignant cells require large quantities of iron in order to proliferate. Iron is also an important mediator of immune functions, including tumor surveillance carried out by the immune cells (9). Cytokine production in macrophages, a key aspect of host defense, is regulated by their iron content (11). Ideal iron intake must therefore be carefully balanced between iron deficiency and iron excess, since both can have potentially crucial clinical consequences with regard to cancer development. To date, however, although a large number of studies have comprehensively investigated and reviewed the role of excess iron in cancer initiation and progression $(5,9,10,12-14)$, potentially tumorigenic effects of iron deficiency have been largely neglected and are not yet well defined (4). This certainly deserves more research, since iron deficiency occurs particularly frequently in patients with $\mathrm{CRC}$, both at the time of diagnosis and throughout the duration of disease (15-17).

Just as the effects of excess iron intake can potentially influence both the etiology and prognosis of CRC, so too can the physiological effects of iron deficiency (18-20). The risk of CRC has been found to be significantly elevated among patients with iron deficiency anemia (IDA) $(15,16,21)$. Moreover, iron deficiency is evidentially associated with shorter survival times in patients with cancer (19). These findings are not surprising, since iron deficiency can limit hematopoiesis, a prerequisite for immune cell production, and iron is necessary for the correct functioning of the immune cells $(22,23)$. Thus, in cancer patients, iron deficiency can result in a diminished immune response and, consequentially, an impaired treatment response, a poor prognosis and reduced overall survival (18-20). In this review, we investigate the flipside of the coin regarding the role of iron in cancer, addressing consequences of iron deficiency on immune functions key to tumor development and progression, particularly in CRC, and elucidating current options for iron therapy to limit these outcomes.

\section{DEFINITION OF IRON DEFICIENCY}

Iron deficiency, with or without anemia, is the most frequent hematological manifestation in individuals with cancer, occurring in over $40 \%$ of patients. In patients with CRC, the reported rate is even higher, at around $60 \%(17,24,25)$. Two forms of iron deficiency can be observed in patients with

\footnotetext{
Abbreviations: AID, absolute iron deficiency; CAT, catalase; $\mathrm{CHr}$, hemoglobin content of reticulocytes; CRC, colorectal cancer; EMT, epithelial to mesenchymal transition; ESA, erythropoiesis-stimulating agent; Fe-S cluster, iron-sulfur cluster; FID, functional iron deficiency; GSH-Px, glutathione peroxidase; $\mathrm{Hb}$, hemoglobin; HIF, hypoxia-inducible factor; IDA, iron deficiency anemia; IFN, interferon; IL, interleukin; JHDM, Jumonji-C (JmjC)-domain-containing histone demethylase; MCV, mean corpuscular volume; MiRNA, microRNA; NF, nuclear factor; NK, natural killer; MPO, myeloperoxidase; RBC, red blood cell; REDOX, oxidationreduction; SF, serum ferritin; SOD, superoxide dismutase; TNF, tumor necrosis factor; TSAT, transferrin saturation; ZnPP, zinc protoporphyrin; sTfR, soluble transferrin receptor; UIBC, unsaturated iron binding capacity; VEGF, vascular endothelial growth factor; VHL, von Hippel-Lindau; \%HYPO, percentage of hypochromic erythrocytes.
}

cancer: absolute iron deficiency (AID) and functional iron deficiency (FID).

Whereas AID is characterized by depleted iron stores and inadequate iron supply, in FID, iron stores are adequate, but there is insufficient iron supply for erythropoiesis and other irondependent pathways $(26,27)$. The main cause of FID in cancer is the release of cancer-associated pro-inflammatory cytokines such as interleukin (IL)-6, IL-1, TNF- $\alpha$, and IFN- $\gamma$. These cytokines upregulate hepcidin synthesis, thus reducing the quantity of iron released into the circulation (27-29). FID may also develop due to chemo- and/or radiotherapy-induced myelosuppression or increased erythropoiesis under therapy with erythropoiesisstimulating agents (ESAs) $(27,29)$. Chronic kidney disease, a frequent comorbidity in cancer patients, can cause FID by reducing erythropoiesis and increasing levels of hepcidin $(30,31)$. FID is one of the major contributors to anemia of chronic disease (ACD), in this context also known as anemia of cancer or cancer-related anemia $(29,32)$.

In AID, on the other hand, iron stores are genuinely depleted. Nutritional deficiencies (e.g., malabsorption, tumorinduced anorexia, malnutrition) and especially manifest or occult blood loss, which are not uncommon in CRC, contribute to AID $(26,27,29)$.

Figure 1 presents an overview of the consequences of iron deficiency and anemia in patients with cancer.

\section{Clinical Insight: Diagnosing Iron Deficiency in Patients With Cancer}

Differentiation between AID and FID is essential, since the specific etiology of iron deficiency in patients with cancer is an important determinant of the treatment approach $(26,27,33,34)$.

Analysis of iron supply in the bone marrow with Perls' Prussian blue staining is the "gold standard" for diagnosis of iron deficiency (35). However, this technique is costly, highly invasive and non-automated, as a result of which it is largely impracticable in routine practice.

In healthy individuals, serum ferritin (SF) is recognized as a marker of iron stores, while other parameters, such as transferrin saturation (TSAT), mean corpuscular volume (MCV), percentage of hypochromic erythrocytes (\%HYPO), Hb content of reticulocytes $(\mathrm{CHr})$, soluble transferrin (sTfR), red blood cells (RBCs) and zinc protoporphyrin ( $\mathrm{ZnPP}$ ) reflect the amount of biologically available iron $(26,27)$. However, most of these parameters are altered in patients with cancer. Therefore, the differentiation of types of iron deficiency in this setting poses multiple challenges (27).

Iron deficiency is defined as transferrin saturation (TSAT) $<$ $20 \%$, and can be further characterized as AID (SF $<100 \mathrm{ng} / \mathrm{mL})$ or FID (SF $>100 \mathrm{ng} / \mathrm{mL})(27,33,34)$. Since SF behaves as an acute-phase protein, due to the presence of cancer-related inflammation, its cut-off point is higher in patients with cancer than in persons without inflammatory disease (cut-off for SF in the latter is $30 \mathrm{ng} / \mathrm{mL}$ ) (34). In addition to the more established markers TSAT and SF, ZnPP could represent a valuable addition to differential diagnostics, since it has been found to be increased in $\operatorname{AID}(34,36,37)$. While levels of soluble transferrin receptor 


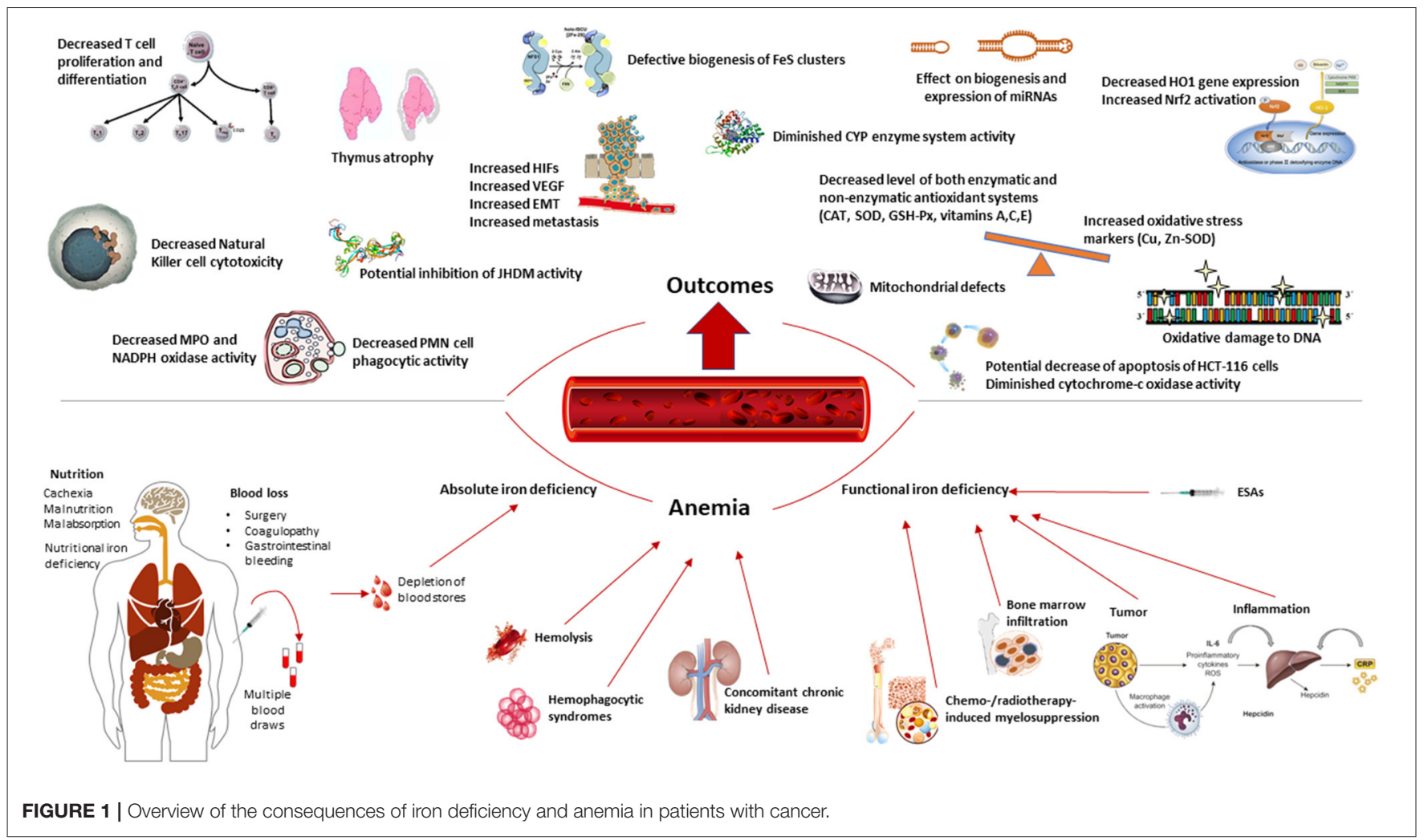

(sTfR) have also been reported to be increased in AID and reduced in FID $(27,32)$, its levels may decrease following chemotherapy and increase after ESA treatment. Therefore, sTfR and markers related to sTfR, such as sTfR/log ferritin index, are less suitable as markers in an oncological setting $(32,34,37)$. Other markers of iron deficiency, including $\mathrm{CHr}$, \% HYPO, MCV, and RBCs, fail to discriminate between AID and FID (34).

Measurement of circulating hepcidin could offer additional utility, not only in assessing iron status, but also in predicting response to iron therapy $(38,39)$. As yet, however, there is neither a validated clinical cut-off for hepcidin nor a simple standard test that would allow it to be fully used in clinical practice $(27,38)$.

\section{IMPACTS OF IRON DEFICIENCY ON CANCER}

Iron has anti-inflammatory and antioxidant properties and is vitally involved in functions of the immune system (4, 20,40 ). It also plays an indispensable role in many other essential physiological processes, such as cell proliferation and differentiation, the maintenance of intestinal health, DNA synthesis and repair, and the metabolic breakdown of drugs and toxins (41-43). Iron homeostasis $(23,44,45)$ and the role of iron in the initiation, progression and therapy of cancer have already been comprehensively reviewed in numerous publications $(9,10$, $12,13,46)$. In this section, we specifically focus on the impacts of iron deficiency on CRC, from basic science to clinical outcomes (Figure 1).

\section{Iron Deficiency and Cancer Epigenetics}

Epigenetic mechanisms have emerged as major actors that play diverse and important roles in the initiation and progression of cancer (47-49). While the role of iron in epigenetics has been described, the underlying mechanisms have not yet been thoroughly elucidated. Iron is essential for iron-sulfur (Fe-S) cluster synthesis in every cell of the body (50) and it is known that the key enzymes of DNA duplication, repair, and epigenetics have $\mathrm{Fe}-\mathrm{S}$ clusters as prosthetic groups (50-54). Iron deficiency causes defective biogenesis of the Fe-S clusters, inducing DNA replication stress and genome instability, both of which are indications of malignant transformation (20,54).

Jumonji-C (JmjC)-domain-containing histone demethylases (JHDMs) affect gene expression by demethylating lysine residues of histone tails, the most common sites of post-translational changes. Genetic alterations in JHDMs have been reported in various human cancers (55-57). Consequently, JHDMs are believed to be involved in oncogenesis (55). JHDMs are irondependent enzymes, having iron as a cofactor $(51,57)$. Therefore, iron deficiency might inhibit the activity of JHDMs, with possible oncologically relevant effects. Furthermore, hypoxia, a common feature of iron deficiency, has also been found to result in a loss of JHDM activity and probably contribute to changes in chemokine expression (56). The role of JHDMs can be two-sided, depending 
on the cancer type. Overall, therefore, it is important to maintain optimal iron levels (55).

The role of microRNAs (miRNAs), members of the noncoding RNA family, in the initiation, progression, metastasis and invasive activity of tumors has been characterized over the past decade. miRNAs are evolutionarily conserved, endogenous, single-stranded small RNAs of 18-22 nucleotides in length, that are encoded by eukaryotic genomic DNA. Aberrant expression of miRNAs may modify the normal expression of various genes including oncogenes and tumor-suppressor genes (47, 58). Ultimately, dysregulation of miRNA expression and related biological processes leads to poor outcomes in terms of cancer progression and development, and also to poorer therapeutic response (58-60). In addition, $\sim 50 \%$ of miRNAs are located at genomic cancer-associated regions of loss of heterozygosity or loss of amplification and at fragile sites within chromosomes, underlining the important role of miRNAs in tumorigenesis (61).

Iron deficiency is suspected to affect miRNA biogenesis and expression and alter miRNA-mediated gene regulation networks by causing defective heme biosynthesis and degradation, hypoxia and increased ROS (62-66). Thus, iron deficiency can also increase the risk of tumorigenesis and lead to poor cancer prognosis and poor therapeutic outcomes by negatively influencing the gene regulation system of miRNAs (67).

Hypoxia, a common feature of iron deficiency, has been demonstrated to play a major part in tumor progression and treatment resistance in mice by corrupting the von HippelLindau (VHL) gene, the master regulator of hypoxia-inducible factor (HIF) and thus a tumor suppressor (68). In iron-deficient, immunodeficient mouse xenograft models, the Notch signaling pathway was shown to be disrupted and expression of the transcription factor Snail elevated (69). Snail has numerous effects relevant to tumor growth, metastasis and treatment resistance: Its increased expression promotes cell motility and invasiveness by altering epithelial-mesenchymal transition (by repressing epithelial and enhancing mesenchymal markers). Furthermore, Snail endows stem cell-like characteristics on tumor cells, thus increasing therapy resistance (70).

Iron deficiency, through hypoxia, has been associated with enhanced expression of BCL2L1, the protein-coding gene that inhibits mitochondria-mediated cell death. Furthermore, iron deficiency has been shown to inhibit expression not only of CTSZ, the gene for the cysteine protease cathepsin Z, which has been associated with malignancy and inflammation, but also of CASP5, the gene for the cysteine peptide Caspase 5, which is involved in cellular apoptosis (71).

Iron deficiency is therefore associated with a variety of epigenetic changes and epigenetic mechanisms that are likely associated with oncogenesis. However, their role in cancer development and progression remains to be fully elucidated.

\section{Iron Deficiency and Pro-oxidant and Antioxidant Activities}

It has been suggested that iron deficiency might cause an imbalance of the pro- and anti-oxidant systems (REDOX) (20). When iron is lacking, the level of both enzymatic and non-enzymatic antioxidant systems, such as catalase (CAT), superoxide dismutase (SOD), glutathione peroxidase (GSH-Px) and vitamins $\mathrm{A}, \mathrm{C}$, and $\mathrm{E}$ have been found to be decreased $(6,72-74)$. On the other hand, oxidative stress markers like $\mathrm{Cu}$ and $\mathrm{Zn}-\mathrm{SOD}$ are increased $(20,75)$. These changes lead to an increased generation of reactive oxygen species (ROS), accompanied by a decrease in the body's total antioxidant capacity $(74,76-78)$. While ROS display varying reactivities toward different targets, they share the ability to damage cells by oxidizing proteins, lipids and DNA. This potential of ROS to cause cell damage and DNA mutation suggests that it may be directly or indirectly associated with tumor cell development, metastasis, tumor aggressiveness and treatment resistance as a reflection of accumulated ROS damage over time $(20,79,80)$.

It has been demonstrated that by increasing oxidative stress, iron deficiency can cause damage to the mitochondria, corrupting mitochondrial DNA (81). Mitochondria are organelles of the cell that are primarily responsible for oxidative phosphorylation, the production of intracellular energy from oxygen and nutrients, as well as heme synthesis (82) and assembly of eukaryotic iron-sulfur $(\mathrm{Fe}-\mathrm{S})$ protein clusters (83). Mitochondria are also responsible for autoreproduction. Disruption of mitochondrial functions can therefore impair the integrity of the nuclear genome (84).

Hemoproteins are conjugated proteins with a variety of structures and functions that contain a non-protein component or prosthetic group called heme (or a derivative thereof). Increased ROS due to oxidative stress may induce the hemoproteins to discharge these heme groups, resulting in circulating free heme that can trigger additional production of free radicals. There are a number of mechanisms that can counteract pro-oxidant effects of free heme, such as rapid induction of heme oxygenase-1 gene (HMOX1) transcription and heme oxygenase-1 (HO-1) isoenzyme protein expression, which generates rapid catabolism of free heme in order to limit resultant cell damage $(85,86)$. As well as being involved in cellular homeostasis, $\mathrm{HO}-1$ plays an important part in preventing oxidative tissue damage and mediating intracellular inflammatory mechanisms, apoptosis and cell proliferation (85). Lai et al. (87) reported that without adequate iron, HCT-116 human colon adenocarcinoma cells were unable to express the HO-1 gene completely, in response to toxicity. Since iron is essential for $\mathrm{HO}-1$ gene expression, iron deficiency might lead to decreased cytoprotection through $\mathrm{HO}-1$ expression (20).

Heme is an integral part of the CYP (intestinal cytochrome P450) antioxidant enzyme system (88-90). Iron deficiency has been shown to diminish CYP system activity in intestinal cells. Both in a xenograft murine model and in CRC cells, CYP2S1 gene depletion was identified to promote colorectal carcinogenesis (91-93). Thus, the effects of iron deficiency on heme synthesis can interfere with the CYP system, posing a risk factor for CRC.

In vitro studies in human brain cells have shown iron deficiency to result in significant reduction of the hemecontaining electron transport protein (cytochrome-c oxidase/complex IV) (94). This has been shown to cause 
impairment of the heme metabolism, an increase in oxidative stress, and mitochondrial dysfunction (94). All of these are characteristic indications of cancer $(20,95)$.

The transcription factor Nrf2 (nuclear factor-E2-related factor-2) functions as a cellular sensor for oxidative stress. The genetic transcription of phase-II proteins via Nrf2 activation probably represents the most important signaling pathway for the body's immune response to oxidative stress and toxins. Nrf2 thus plays an essential role in cell protection. Iron deficiency has been found to activate autophagy and Nrf2 signaling for oxidative stress (96). Nrf2 activation has been implicated in cancer and is associated with a poor outcome and reduced survival in tumor types such as non-small cell lung cancer $(97,98)$. It has been proposed that constitutive activation of Nrf2 may encourage oncogenesis $(99,100)$ through actions promoting angiogenesis, metabolic reprogramming, chronic proliferation, and resistance to cell death $(101,102)$. Therefore, iron deficiency may promote oncogenesis by activating autography and Nrf2 signaling for oxidative stress.

\section{Iron Deficiency, Immune Response, and Cell Function}

The interplay of iron homeostasis with cellular immune responses is complex and context dependent. Impairment of cellular immunity and antimicrobial activities of immune cells due to iron deficiency may create a microenvironment unconducive to the immunosurveillance mechanisms of the immune system that should identify and eliminate potential for malignant transformation. Furthermore, within the modified tumor microenvironment, immune cells may themselves exert a pro-tumorigenic response $(4,14,20,85)$.

The nuclear factor $(\mathrm{NF}-\kappa \mathrm{B})$ and hypoxia-inducible factors (HIFs) are transcription factors that are critical to immune system regulation (103). The physiology of tumor cells allows them to grow and multiply rapidly and avoid apoptosis. Also characteristic of these cells are their capacities to ignore growthinhibitory signals, to instigate angiogenesis, tissue invasion and metastasis, and to replicate infinitely. Almost all of the genes involved in the mediation of these processes are regulated by NF-кB transcription (104). Low levels of intracellular iron evidentially reduce phosphorylation of Re1A, a subunit of the NF- $\mathrm{B}$ family of genes, and impair prolyl hydroxylation of HIFs (71, 105). Iron deficiency per se and iron deficiencyinduced hypoxia can trigger the activation of HIFs, which are known to mediate cancer progression by upregulating target genes associated with angiogenesis and the metabolic reprogramming of tumor cells $(106,107)$, thus causing resistance to chemo- and radiotherapies $(108,109)$. HIF-1 $\alpha$ plays a key role in the growth, progression and metastasis of solid tumors $(110,111)$. Iron deficiency has been found to promote HIF-1 transcription and inhibit HIF-2 transcription, thus corrupting the synergistic signaling pathways between the HIFs and NF$\kappa \mathrm{B}$ (71). Consequently, iron deficiency may weaken the immune response, increasing both the risk of oncogenesis and the probability of a poor prognosis and resistance to therapy when malignancy occurs.
Cellular iron depletion induced by the iron chelator desferoxamine mesylate (DFO) has been shown to increase HIF$1 \alpha$ (112). The transcription factor HIF- $1 \alpha$ mediates expression of vascular endothelial growth factor (VEGF), a potent inducer of malignant angiogenesis and metastasis. Thus, iron deficiency has been reported to have important effects on HIF- $1 \alpha$ stabilization, VEGF formation, angiogenesis and tumor progression in breast cancer, in both in vitro and in vivo studies $(68,113)$. Jacobsen et al. (114) found increased VEGF levels to be associated with a poor outcome in human renal cell carcinoma. Moreover, in one of these models, iron supplementation was found to significantly decrease VEGF levels in hypoxia, indicating a role for iron in counteracting HIF- $1 \alpha$ stabilization and thus, possibly, in preventing angiogenesis (113).

Myeloperoxidase (MPO) and NADPH oxidase are enzymes that play a key role in interferon- $\gamma$ (IFN- $\gamma$ ) induction by monocytes, and in microbial killing and phagocytosis by means of ROS production in neutrophils. These enzymes are iron dependent (115-118): Their catalytic activity is suppressed when iron deficiency is present, causing phagocytosis to be impaired. As a result, susceptibility to infections and tumor development may be increased $(20,118)$.

Natural killer (NK) cells are cytotoxic effector lymphocytes that perform unique functions including immunosurveillance and anti-tumor actions within the innate immune system (119). Hypoxia, which is characteristic of the iron deficient state, has been shown to inhibit the expression of vital activating NKcell receptors and NK-cell ligands on tumor cell membranes $(120,121)$. Iron deficiency therefore disrupts the cytotoxic and specifically anti-tumor activities of NK cells and is conducive to oncogenesis and tumor growth.

Lymphocytes, comprising natural killer cells, $\mathrm{T}$ cells and B cells, are the major cellular constituents of cell mediated immunity. Cytotoxic $\mathrm{T}$ cells have several functions, one of which is the lysis of tumor cells. Iron deficiency has been shown to inhibit $\mathrm{T}$ cell proliferation and secretion of the potent anti-tumor cytokine IFN- $\gamma$ (122). In murine models, iron deficiency was found to lead to atrophy of the thymus gland and the reduced excretion of CD28 thymocytes and spleen cells, causing impairment to lymphocytic motility and functions $(123,124)$. In addition, protein kinase- $C$ translocation from cytosol to the plasma membrane, vitally necessary for $\mathrm{T}$ cell migration and immunological synapse, is reduced in the iron deficient state $(125,126)$. Furthermore, iron deficiency inhibits overall the expression of various diversely acting cytokines from cells of the immune system (127129). Cell mediated immunity is therefore impaired due to iron deficiency, paving the way for cancer development and growth.

It has been demonstrated that intracellular iron plays a key role in apoptosis of HCT-116 (human cancer) cells (130). Furthermore, cytochrome-c oxidase activity, a significant marker of apoptosis resistance, is evidentially diminished in the presence of iron deficiency $(131,132)$. Therefore, the cancer-related effects of iron deficiency may influence not only tumor development and progression, but also apoptosis and treatment response. 


\section{EVIDENCE FROM HUMAN CLINICAL STUDIES OF IRON DEFICIENCY ANEMIA IN RELATION TO COLORECTAL CANCER}

The abundant biological and immunological evidence describing important cancer-related effects of iron deficiency has direct implications for human health. Clinical and epidemiological studies have focused on various aspects of the relationship between iron deficiency and CRC, from etiology to progression and metastasis, therapeutic response and long-term outcomes.

Studies of patients with CRC found a significant association with low transferrin saturation in a cohort of Californian males (133) and with low serum ferritin in a case-control nested study of New York females (134). In another cohort study, men and postmenopausal women with iron deficiency without anemia had a five-fold and those with IDA a 31-fold increased risk of developing gastrointestinal cancer in comparison to individuals with normal hemoglobin $(\mathrm{Hb})$ and TSAT levels (15).

In a large cohort of 965 men and women aged 50-75 years, Bird et al. (135) found a U-shaped relation between iron intake and colorectal polyps, with those consuming high $(>27.3$ $\mathrm{mg} /$ day) or low ( $<11.6 \mathrm{mg} /$ day) quantities of iron more likely to develop colorectal polyps, a precursor lesion to CRC. In line with this, Cross et al. (136) showed that CRC risk was inversely associated with serum ferritin levels and positively associated with serum unsaturated iron binding capacity (UIBC). Moreover, serum iron and TSAT were found to have an inverse association with the risk of colon cancer, specifically (136). In a recent study by Hamarneh et al. (137) assessing risk factors for CRC following a positive fecal immunochemical test, IDA was reported as a significant risk factor for CRC [OR 7.93, 95\% Cl (2.90-21.69), $p<0.001]$ independent of age. While the above findings suggest that iron deficiency could contribute to the pathogenesis of CRC, just as excessive iron intake does, the mechanisms are not yet fully understood. However, as presented above, preclinical research points to a role of iron deficiency in blunting the immune response, allowing tumor cell invasion under diminished immunosurveillance or switching to a pro-tumorigenic immune cell function in the tumor microenvironment $(4,9,22,23)$.

Not only may iron deficiency substantially influence oncogenesis, but it has also been found to influence oncological outcomes in patients with CRC. Zhen et al. (138) investigated long term effects of iron deficiency on the outcomes of 644 patients (19-83 years) with TNM stage II CRC and found IDA to be an independent predictor of long-term outcome in patients with T3N0M0 stage colon cancer. Patients with IDA had inferior outcomes and presented with worse tumor staging and lower disease-free survival than non-anemic patients (138). These findings suggest that IDA can influence CRC prognosis and outcomes, presumably by inhibiting immune system mechanisms that limit tumor growth, hindering responsiveness to treatments such as chemotherapy or surgery, and restricting the immune system's response to circulating tumor cells that can develop into distant metastasis $(4,9,139)$. Lorenzi et al. (140) found that patients with both high and low serum ferritin levels who underwent curative or palliative surgery had shorter survival after a follow up period of at least 5 years in comparison to those with normal levels. Another study by An et al. (141) showed that patients with preoperative anemia treated with combined FOLFOX-based adjuvant chemotherapy had a worse prognosis than those without anemia. Additionally, a systematic review of 60 studies identified a $65 \%$ overall elevated mortality risk among cancer patients with anemia in comparison with those without anemia (19).

Overall, therefore, the evidence from epidemiological and clinical research corroborates data from preclinical studies, suggesting that iron deficiency, like iron surplus, might have a considerable negative influence with regard to oncogenesis, tumor progression and individual outcomes. Iron deficiency, with or without anemia, is associated with a poor prognosis, worse tumor staging, lower disease-free survival rates and a poorer response to oncological therapies in patients with CRC.

\section{ON A THERAPEUTIC KNIFE-EDGE: IRON REPLACEMENT THERAPY IN PATIENTS WITH COLORECTAL CANCER AND IRON DEFICIENCYIANEMIA}

There are currently three main treatment approaches for iron deficiency in the context of CRC; blood transfusions (RBC transfusions), erythropoiesis-stimulating agents (ESAs) and iron supplementation $(26,34)$. Since both RBC transfusions and ESAs are, like iron deficiency/anemia, independently associated with an increased risk of CRC recurrence and mortality (142-144), the use of iron substitution therapy to reverse anemia has gained more attention. In principle, iron can be replaced either orally or intravenously.

\section{Oral Iron}

Oral substitution of iron has long been favored due to its simplicity and low costs, and as a result of lingering safety concerns due to adverse events associated with early intravenous iron compounds. However, its suitability in cancer patients is generally limited by concurrent inflammation, gastrointestinal discomfort and polypharmacy. Furthermore, oral iron has not been associated with consistent clinical or hematological improvement in patients with cancer $(82,145-147)$. On the contrary; it has been found to be ineffective in individuals with cancer and especially CRC, since intestinal iron absorption is greatly reduced in these patients (nearly $95 \%$ of the iron being excreted) (33). Furthermore, the increased availability of iron in the gut due to reduced intestinal iron absorption may support the proliferation of pathogenic gut bacteria conducive to tumor progression in preference to protective passenger bacteria that are more likely to hinder disease progression (148). As for the very small quantity of iron absorbed, most remains trapped within the enterocytes, where it is largely blocked by inflammatory cytokines and thus cannot be metabolized $(33,149)$. Overall, 
therefore, oral iron is unsuitable for iron replacement in patients with CRC.

\section{Intravenous Iron}

Intravenous (IV) iron can overcome the absorptive inflammatory blockade of iron, since iron is directly captured by the macrophages (33). There is growing evidence to support benefits of IV iron therapy (without additional ESAs) in patients with cancer (150-160) and IV iron has been shown to optimize preoperative hemoglobin levels specifically in patients with CRC (158-163). On the other hand, in the extended IVICA trial, a randomized study including 116 patients with anemia and colorectal cancer treated preoperatively with oral or IV iron, no significant difference was found for 5-year overall survival or disease-free survival (164). There are some concerns about the possible role of iron overload in cancer, including promotion of tumor growth, enhanced oxidative stress and poor disease progression (165-167). Wilson et al. (168) suggest that "iron therapy may worsen colorectal tumor prognosis by supporting colorectal tumor growth and increasing the metastatic potential." However, there is no direct evidence from experimental studies to substantiate this hypothesis and the clinical applicability of such experimental data in patients with cancer is limited, since they are based on high iron doses, differing routes of injection and a variety of iron formulations that are not typically used in clinical settings $(27,169)$. Furthermore, iron overload is rare in patients with cancer (34).

In rodent models of CRC induced by inflammatory or carcinogenic agents, whereas elevated oral iron intake was shown to increase the incidence of tumors, systemic (IV) iron supplementation did not have the same effect $(170,171)$. This suggests that increased luminal iron, but not systemic iron levels, increase colorectal carcinogenesis in inflammatory models of CRC (172, 173). Radulescu et al., who showed in a rodent model that luminal iron cooperates with Apc (adenomatous polyposis coli gene) loss to promote intestinal tumorigenesis, propose that in patients with CRC, a combination of colonic luminal iron chelation and concurrent systemic iron replacement therapy would both resolve anemia and at the same time diminish the carcinogenic pool of residual iron within the colon (174).

Evidence from prospective clinical trials describing outcomes of IV iron therapy (alone or in combination with ESAs) in an oncological population are relatively scarce but their results are in line with the findings of rodent model studies. Short-term studies are reassuring, having not shown increased tumor progression in patients treated with IV iron and ESAs (34). One prospective randomized controlled trial evaluating treatment with IV iron and ESAs in patients with cancer (175), with a median follow-up period of 1.4 years, failed to find any negative effects on long-term outcomes or survival. A retrospective cohort study of patients who underwent surgery for CRC, with an extended follow-up period (median 3.9 years), confirmed that overall and disease-free survival did not significantly differ in subjects treated with IV iron (in this case, ferric carboxymaltose at a dose of 1,000$2,000 \mathrm{mg}$ ) as compared with a matched group not receiving IV iron (176). A comprehensive review of iron dextran use by Gilreath et al. concluded that there was no clinical evidence to support an elevated risk of cancer growth due to iron overload (167).

Regarding the risk of infections, no alarming signs have emerged in patients with cancer treated with IV iron. Nevertheless, given the role of iron in immune response and microbial proliferation (177), current guidelines prudently advise that IV iron should not be administered to patients who have, or are suspected to have, active infections (34).

No increase in cardiovascular morbidity has been observed in connection with IV iron therapy (82, 145, 178-180). However, it is recommended to avoid concomitant administration of IV iron and cardiotoxic chemotherapy: IV iron should be administered either before or after application of chemotherapy, or at the end of the chemotherapy treatment cycle (34).

\section{CONCLUSION}

In contrast to the large amount of research already dedicated to the effects of excess iron as a probable (co-)trigger and driver of oncogenesis, the role of iron deficiency has been largely neglected and-on the evidence of the reviewed preclinical and clinical data-possibly underestimated. In particular, iron is vital for optimal functioning of the immune system, playing major roles in a multitude of different immune processes and pathways. Iron deficiency influences crucial mechanisms such as immune surveillance, gene regulation and cell apoptosis, all of which are key to host defense against malignant transformation and tumor growth. Clinical studies in patients with cancer and iron deficiency/anemia suggest that that unlike oral iron, IV iron therapy (with/without ESAs) improves overall outcomes without increasing risk of infection or cardiovascular morbidity. Excess (uningested/residual) oral iron can cause oncogenic effects in the intestinal tract and is thus generally unsuitable for patients with CRC (although its use may occasionally be justified, employing "defensive" dosing strategies). In general, IV iron does not appear to have this potential for local exacerbation, as confirmed by rodent studies. Iron overload is rarely seen in patients with cancer and there is no clinical evidence that IV iron negatively affects tumor progression. Nevertheless, in view of the abounding evidence of effects of iron overload on tumor growth, we suggest that IV iron should be cautiously supplemented with the goal of avoiding anemia and maintaining iron stores. Additional research is needed to confirm the appropriateness of IV iron replacement in patients with cancer, to explore the feasibility of concurrent luminal iron chelation, to determine target levels for iron store maintenance, and to shed further light on the effects of chronic iron deficiency on iron-dependent mechanisms in the context of the tumor microenvironment. 


\section{AUTHOR CONTRIBUTIONS}

AA performed the initial literature search. All authors participated in the data analysis, preparation of the manuscript draft, reviewed the manuscript for important intellectual content and approved the final version for submission.

\section{REFERENCES}

1. Bray F, Ferlay J, Soerjomataram I, Siegel RL, Torre LA, Jemal A. Global cancer statistics 2018: GLOBOCAN estimates of incidence and mortality worldwide for 36 cancers in 185 countries. CA Cancer J Clin. (2018) 68:394424. doi: 10.3322/caac. 21492

2. Keum N, Giovannucci E. Global burden of colorectal cancer: emerging trends, risk factors and prevention strategies. Nat Rev Gastroenterol Hepatol. (2019) 16:713-32. doi: 10.1038/s41575-019-0189-8

3. Dekker E, Tanis PJ, Vleugels JLA, Kasi PM, Wallace MB. Colorectal cancer. Lancet. (2019) 394:1467-80. doi: 10.1016/S0140-6736(19) 32319-0

4. Phipps O, Brookes MJ, Al-Hassi HO. Iron deficiency, immunology, and colorectal cancer. Nutr Rev. (2020) 79:88-97. doi: 10.1093/nutrit/nuaa040

5. Fonseca-Nunes A, Jakszyn P, Agudo A. Iron and cancer risk-a systematic review and meta-analysis of the epidemiological evidence. Cancer Epidemiol Biomarkers Prev. (2014) 23:12-31. doi: 10.1158/1055-9965.EPI-13-0733

6. Nelson RL. Iron and colorectal cancer risk: human studies. Nutr Rev. (2001) 59:140-8. doi: 10.1111/j.1753-4887.2001.tb07002.x

7. Stevens RG, Jones DY, Micozzi MS, Taylor PR. Body iron stores and the risk of cancer. $N$ Engl J Med. (1988) 319:104752. doi: 10.1056/NEJM198810203191603

8. Knekt P, Reunanen A, Takkunen H, Aromaa A, Heliövaara M, Hakulinen T. Body iron stores and risk of cancer. Int J Cancer. (1994) 56:37982. doi: $10.1002 / \mathrm{ijc} .2910560315$

9. Pfeifhofer-Obermair C, Tymoszuk P, Petzer V, Weiss G, Nairz M. Iron in the tumor microenvironment-connecting the dots. Front Oncol. (2018) 8:549. doi: 10.3389/fonc.2018.00549

10. Brown RAM, Richardson KL, Kabir TD, Trinder D, Ganss R, Leedman PJ. Altered iron metabolism and impact in cancer biology, metastasis, and immunology. Front Oncol. (2020) 10:476. doi: 10.3389/fonc.2020.00476

11. Ganz T. Iron and infection. Int J Hematol. (2018) 107:715. doi: 10.1007/s12185-017-2366-2

12. Torti SV, Manz DH, Paul BT, Blanchette-Farra N, Torti FM. Iron and cancer. Annu Rev Nutr. (2018) 38:97125. doi: 10.1146/annurev-nutr-082117-051732

13. Jung $M$, Mertens $C$, Tomat E, Brüne B. Iron as a central player and promising target in cancer progression. Int J Mol Sci. (2019) 20:273. doi: 10.3390/ijms20020273

14. Vela D. Iron in the tumor microenvironment. Adv Exp Med Biol. (2020) 1259:39-51. doi: 10.1007/978-3-030-43093-1_3

15. Ioannou GN, Rockey DC, Bryson CL, Weiss NS. Iron deficiency and gastrointestinal malignancy: a population-based cohort study. Am J Med. (2002) 113:276-80. doi: 10.1016/S0002-9343(02)01214-7

16. James MW, Chen CM, Goddard WP, Scott BB, Goddard AF. Risk factors for gastrointestinal malignancy in patients with iron-deficiency anaemia. Eur J Gastroenterol Hepatol. (2005) 17:1197-203. doi: 10.1097/00042737-200511000-00008

17. Ludwig $\mathrm{H}$, Müldür E, Endler G, Hübl W. Prevalence of iron deficiency across different tumors and its association with poor performance status, disease status and anemia. Ann Oncol. (2013) 24:1886-92. doi: 10.1093/annonc/mdt118

18. Paitan V, Alcarraz C, Leonardo A, Valencia G, Mantilla R, Morante Z, et al. Anemia as a prognostic factor in cancer patients. Rev Peru Med Exp Salud Publica. (2018) 35:250-8. doi: 10.17843/rpmesp.2018.352.3171

19. Caro JJ, Salas M, Ward A, Goss G. Anemia as an independent prognostic factor for survival in patients with cancer: a systemic,
ACKNOWLEDGMENTS

The authors gratefully acknowledge the assistance of Janet Collins (Interdisziplinäres Crohn Colitis Centrum Rhein-Main, Frankfurt am Main, Germany) in editing and proofreading the manuscript.

quantitative review. Cancer. (2001) 91:2214-21. doi: 10.1002/1097 0142(20010615)91:12<2214::AID-CNCR1251>3.0.CO;2-P

20. Zohora F, Bidad K, Pourpak Z, Moin M. Biological and immunological aspects of iron deficiency anemia in cancer development: a narrative review. Nutr Cancer. (2018) 70:546-56. doi: 10.1080/01635581.2018.14 60685

21. Nakama H, Zhang B, Fattah AS, Zhang X. Colorectal cancer in iron deficiency anemia with a positive result on immunochemical fecal occult blood. Int J Colorectal Dis. (2000) 15:271-4. doi: 10.1007/s0038400 00255

22. Rieger MA, Schroeder T. Hematopoiesis. Cold Spring Harb Perspect Biol. (2012) 4:a008250. doi: 10.1101/cshperspect.a008250

23. Muckenthaler MU, Rivella S, Hentze MW, Galy B. A red carpet for iron metabolism. Cell. (2017) 168:344-61. doi: 10.1016/j.cell.2016.12.034

24. Ludwig H, Van Belle S, Barrett-Lee P, Birgegård G, Bokemeyer C, Gascón P, et al. The European Cancer Anaemia Survey (ECAS): a large, multinational, prospective survey defining the prevalence, incidence, and treatment of anaemia in cancer patients. Eur J Cancer. (2004) 40:2293306. doi: 10.1016/j.ejca.2004.06.019

25. Ploug M, Kroijer R, Qvist N, Lindahl CH, Knudsen T. Iron deficiency in colorectal cancer patients: a cohort study on prevalence and associations. Colorectal Dis. (2020). doi: 10.1111/codi.15467. Epub ahead of print.

26. Abiri B, Vafa M. Iron deficiency and anemia in cancer patients: the role of iron treatment in anemic cancer patients. Nutr Cancer. (2020) 72:86472. doi: 10.1080/01635581.2019.1658794

27. Busti F, Marchi G, Ugolini S, Castagna A, Girelli D. Anemia and iron deficiency in cancer patients: role of iron replacement therapy. Pharmaceuticals. (2018) 11:94. doi: 10.3390/ph11040094

28. Ganz T, Nemeth E. Iron homeostasis in host defence and inflammation. Nat Rev Immunol. (2015) 15:500-10. doi: 10.1038/nri3863

29. Grotto HZ. Anaemia of cancer: an overview of mechanisms involved in its pathogenesis. Med Oncol. (2008) 25:12-21. doi: 10.1007/s12032-007-9000-8

30. Ueda N, Takasawa K. Role of hepcidin-25 in chronic kidney disease: anemia and beyond. Curr Med Chem. (2017) 24:141752. doi: 10.2174/0929867324666170316120538

31. Ueda N, Takasawa K. Impact of inflammation on ferritin, hepcidin and the management of iron deficiency anemia in chronic kidney disease. Nutrients. (2018) 10:1173. doi: 10.3390/nu10091173

32. Weiss G, Goodnough LT. Anemia of chronic disease. N Engl J Med. (2005) 352:1011-23. doi: 10.1056/NEJMra041809

33. Naoum FA. Iron deficiency in cancer patients. Rev Bras Hematol Hemoter. (2016) 38:325-30. doi: 10.1016/j.bjhh.2016.05.009

34. Aapro M, Beguin Y, Bokemeyer C, Dicato M, Gascón P, Glaspy J, et al. Management of anaemia and iron deficiency in patients with cancer: ESMO clinical practice guidelines. Ann Oncol. (2018) 29 (Suppl. 4):iv96110. doi: 10.1093/annonc/mdx758

35. Grote Beverborg N, Klip IT, Meijers WC, Voors AA, Vegter EL, van der Wal HH, et al. Definition of iron deficiency based on the gold standard of bone marrow iron staining in heart failure patients. Circ Heart Fail. (2018) 11:e004519. doi: 10.1161/CIRCHEARTFAILURE.117.004519

36. Hastka J, Lasserre JJ, Schwarzbeck A, Hehlmann R. Central role of zinc protoporphyrin in staging iron deficiency. Clin Chem. (1994) 40:76873. doi: $10.1093 /$ clinchem/40.5.768

37. Steinmetz HT, Tsamaloukas A, Schmitz S, Wiegand J, Rohrberg R, Eggert J, et al. A new concept for the differential diagnosis and therapy of anaemia in cancer patients. Support Care Cancer. (2010) 19:2619. doi: 10.1007/s00520-010-0812-2 
38. Girelli D, Nemeth E, Swinkels DW. Hepcidin in the diagnosis of iron disorders. Blood. (2016) 127:2809-13. doi: 10.1182/blood-2015-12-639112

39. Prentice AM, Doherty CP, Abrams SA, Cox SE, Atkinson SH, Verhoef $\mathrm{H}$, et al. Hepcidin is the major predictor of erythrocyte iron incorporation in anemic African children. Blood. (2012) 119:1922-8. doi: 10.1182/blood-2011-11-391219

40. Munoz C, Rios E, Olivos J, Brunser O, Olivares M. Iron, copper and immunocompetence. Br J Nutr. (2007) 98 (Suppl. 1):S24-8. doi: 10.1017/S0007114507833046

41. Liu L, Huang M. Essential role of the iron-sulfur cluster binding domain of the primase regulatory subunit Pri2 in DNA replication initiation. Protein Cell. (2015) 6:194-210. doi: 10.1007/s13238-015-0134-8

42. Dostal A, Lacroix C, Pham VT, Zimmermann MB, Del'homme C, BernalierDonadille A, et al. Iron supplementation promotes gut microbiota metabolic activity but not colitis markers in human gut microbiota-associated rats. $\mathrm{Br} \mathrm{J}$ Nutr. (2014) 111:2135-45. doi: 10.1017/S000711451400021X

43. Bohnsack BL, Hirschi KK. Nutrient regulation of cell cycle progression. Annu Rev Nutr. (2004) 24:43353. doi: 10.1146/annurev.nutr.23.011702.073203

44. Hentze MW, Muckenthaler MU, Galy B, Camaschella C. Two to tango: regulation of Mammalian iron metabolism. Cell. (2010) 142:2438. doi: 10.1016/j.cell.2010.06.028

45. Dev S, Babitt JL. Overview of iron metabolism in health and disease. Hemodial Int. (2017) 21 (Suppl. 1):S6-s20. doi: 10.1111/hdi.12542

46. Wang Y, Yu L, Ding J, Chen Y. Iron metabolism in cancer. Int J Mol Sci. (2018) 20:95. doi: 10.3390/ijms20010095

47. Jung G, Hernández-Illán E, Moreira L, Balaguer F, Goel A. Epigenetics of colorectal cancer: biomarker and therapeutic potential. Nat Rev Gastroenterol Hepatol. (2020) 17:111-30. doi: 10.1038/s41575-019-0230-y

48. Sharma S, Kelly TK, Jones PA. Epigenetics in cancer. Carcinogenesis. (2010) 31:27-36. doi: 10.1093/carcin/bgp220

49. Wainwright EN, Scaffidi P. Epigenetics and cancer stem cells: unleashing, hijacking, and restricting cellular plasticity. Trends Cancer. (2017) 3:37286. doi: 10.1016/j.trecan.2017.04.004

50. Camaschella C, Pagani A, Nai A, Silvestri L. The mutual control of iron and erythropoiesis. Int J Lab Hematol. (2016) 38 (Suppl. 1):206. doi: 10.1111/ijlh.12505

51. Wessels I. Epigenetics and metal deficiencies. Curr Nutr Rep. (2014) 3:196203. doi: 10.1007/s13668-014-0091-5

52. Zhang C. Essential functions of iron-requiring proteins in DNA replication, repair and cell cycle control. Protein Cell. (2014) 5:750-60. doi: 10.1007/s13238-014-0083-7

53. Prá D, Franke SI, Henriques JA, Fenech M. Iron and genome stability: an update. Mutat Res. (2012) 733:92-9. doi: 10.1016/j.mrfmmm.2012.02.001

54. Paul VD, Lill R. Biogenesis of cytosolic and nuclear iron-sulfur proteins and their role in genome stability. Biochim Biophys Acta. (2015) 1853:152839. doi: 10.1016/j.bbamcr.2014.12.018

55. Park SY, Park J-W, Chun Y-S. Jumonji histone demethylases as emerging therapeutic targets. Pharmacol Res. (2016) 105:14651. doi: 10.1016/j.phrs.2016.01.026

56. Tausendschön M, Dehne N, Brüne B. Hypoxia causes epigenetic gene regulation in macrophages by attenuating Jumonji histone demethylase activity. Cytokine. (2011) 53:256-62. doi: 10.1016/j.cyto.2010.11.002

57. McCann TS, Sobral LM, Self C, Hsieh J, Sechler M, Jedlicka P. Biology and targeting of the Jumonji-domain histone demethylase family in childhood neoplasia: a preclinical overview. Expert Opin Ther Targets. (2019) 23:26780. doi: 10.1080/14728222.2019.1580692

58. Zamani M, Hosseini SV, Mokarram P. Epigenetic biomarkers in colorectal cancer: premises and prospects. Biomarkers. (2018) 23:105-14. doi: 10.1080/1354750X.2016.1252961

59. Liu Z, Wu R, Li G, Sun P, Xu Q, Liu Z. MiR-592 inhibited cell proliferation of human colorectal cancer cells by suppressing of CCND3 expression. Int $J$ Clin Exp Med. (2015) 8:3490-7.

60. Okugawa Y, Grady WM, Goel A. Epigenetic alterations in colorectal cancer: emerging biomarkers. Gastroenterology. (2015) 149:1204-25.e12. doi: 10.1053/j.gastro.2015.07.011

61. Calin GA, Sevignani C, Dumitru CD, Hyslop T, Noch E, Yendamuri S, et al. Human microRNA genes are frequently located at fragile sites and genomic regions involved in cancers. Proc Natl Acad Sci USA. (2004) 101:29993004. doi: 10.1073/pnas.0307323101

62. Weitz SH, Gong M, Barr I, Weiss S, Guo F. Processing of microRNA primary transcripts requires heme in mammalian cells. Proc Natl Acad Sci USA. (2014) 111:1861-6. doi: 10.1073/pnas.1309915111

63. Bandara KV, Michael MZ, Gleadle JM. MicroRNA biogenesis in hypoxia. Microrna. (2017) 6:80-96. doi: 10.2174/2211536606666170313114821

64. Nallamshetty S, Chan SY, Loscalzo J. Hypoxia: a master regulator of microRNA biogenesis and activity. Free Radic Biol Med. (2013) 64:2030. doi: 10.1016/j.freeradbiomed.2013.05.022

65. Bao B, Azmi AS, Li Y, Ahmad A, Ali S, Banerjee S, et al. Targeting CSCs in tumor microenvironment: the potential role of ROS-associated miRNAs in tumor aggressiveness. Curr Stem Cell Res Ther. (2014) 9:2235. doi: 10.2174/1574888X113089990053

66. Bao B, Ahmad A, Li Y, Azmi AS, Ali S, Banerjee S, et al. Targeting CSCs within the tumor microenvironment for cancer therapy: a potential role of mesenchymal stem cells. Expert Opin Ther Targets. (2012) 16:104154. doi: 10.1517/14728222.2012.714774

67. Schetter AJ, Leung SY, Sohn JJ, Zanetti KA, Bowman ED, Yanaihara $\mathrm{N}$, et al. MicroRNA expression profiles associated with prognosis and therapeutic outcome in colon adenocarcinoma. JAMA. (2008) 299:42536. doi: 10.1001/jama.299.4.425

68. Jian J, Yang Q, Dai J, Eckard J, Axelrod D, Smith J, et al. Effects of iron deficiency and iron overload on angiogenesis and oxidative stress-a potential dual role for iron in breast cancer. Free Radic Biol Med. (2011) 50:8417. doi: 10.1016/j.freeradbiomed.2010.12.028

69. Jian J, Yang Q, Shao Y, Axelrod D, Smith J, Singh B, et al. A link between premenopausal iron deficiency and breast cancer malignancy. BMC Cancer. (2013) 13:307. doi: 10.1186/1471-2407-13-307

70. Wang Y, Shi J, Chai K, Ying X, Zhou BP. The role of snail in EMT and tumorigenesis. Curr Cancer Drug Targets. (2013) 13:96372. doi: $10.2174 / 15680096113136660102$

71. Zhang X, Zhang W, Ma SF, Miasniakova G, Sergueeva A, Ammosova $\mathrm{T}$, et al. Iron deficiency modifies gene expression variation induced by augmented hypoxia sensing. Blood Cells Mol Dis. (2014) 52:3545. doi: 10.1016/j.bcmd.2013.07.016

72. Akça H, Polat A, Koca C. Determination of total oxidative stress and total antioxidant capacity before and after the treatment of iron-deficiency anemia. J Clin Lab Anal. (2013) 27:227-30. doi: 10.1002/jcla.21589

73. Koskenkorva-Frank TS, Weiss G, Koppenol WH, Burckhardt S. The complex interplay of iron metabolism, reactive oxygen species, and reactive nitrogen species: insights into the potential of various iron therapies to induce oxidative and nitrosative stress. Free Radic Biol Med. (2013) 65:117494. doi: 10.1016/j.freeradbiomed.2013.09.001

74. Sies H. Oxidative stress: a concept in redox biology and medicine. Redox Biol. (2015) 4:180-3. doi: 10.1016/j.redox.2015.01.002

75. Toblli JE, Cao G, Oliveri L, Angerosa M. Effects of iron deficiency anemia and its treatment with iron polymaltose complex in pregnant rats, their fetuses and placentas: oxidative stress markers and pregnancy outcome. Placenta. (2012) 33:81-7. doi: 10.1016/j.placenta.2011.11.017

76. Klaunig JE. Oxidative Stress and Cancer. Curr Pharm Des. (2018) 24:47718. doi: 10.2174/1381612825666190215121712

77. Datta S, Cano M, Ebrahimi K, Wang L, Handa JT. The impact of oxidative stress and inflammation on RPE degeneration in non-neovascular AMD. Prog Retin Eye Res. (2017) 60:201-18. doi: 10.1016/j.preteyeres.2017.03.002

78. Chen X, Song M, Zhang B, Zhang Y. Reactive oxygen species regulate T cell immune response in the tumor microenvironment. Oxid Med Cell Longev. (2016) 2016:1580967. doi: 10.1155/2016/1580967

79. Gill JG, Piskounova E, Morrison SJ. Cancer, oxidative stress, and metastasis. Cold Spring Harb Symp Quant Biol. (2016) 81:163-75. doi: 10.1101/sqb.2016.81.030791

80. Reuter S, Gupta SC, Chaturvedi MM, Aggarwal BB. Oxidative stress, inflammation, and cancer: how are they linked? Free Radic Biol Med. (2010) 49:1603-16. doi: 10.1016/j.freeradbiomed.2010.09.006

81. Walter PB, Knutson MD, Paler-Martinez A, Lee S, Xu Y, Viteri FE, et al. Iron deficiency and iron excess damage mitochondria and mitochondrial DNA in rats. Proc Natl Acad Sci USA. (2002) 99:2264-9. doi: 10.1073/pnas.2617 08798 
82. Auerbach M, Ballard H, Trout JR, McIlwain M, Ackerman A, Bahrain $\mathrm{H}$, et al. Intravenous iron optimizes the response to recombinant human erythropoietin in cancer patients with chemotherapy-related anemia: a multicenter, open-label, randomized trial. J Clin Oncol. (2004) 22:13017. doi: 10.1200/JCO.2004.08.119

83. Lill R, Dutkiewicz R, Freibert SA, Heidenreich T, Mascarenhas J, Netz DJ, et al. The role of mitochondria and the CIA machinery in the maturation of cytosolic and nuclear iron-sulfur proteins. Eur J Cell Biol. (2015) 94:28091. doi: 10.1016/j.ejcb.2015.05.002

84. Kaniak-Golik A, Skoneczna A. Mitochondria-nucleus network for genome stability. Free Radic Biol Med. (2015) 82:73104. doi: 10.1016/j.freeradbiomed.2015.01.013

85. Thévenod F. Iron and its role in cancer defense: a double-edged sword. Met Ions Life Sci. (2018) 18:437-67. doi: 10.1515/9783110470734-021

86. Gozzelino R, Jeney V, Soares MP. Mechanisms of cell protection by heme oxygenase-1. Annu Rev Pharmacol Toxicol. (2010) 50:32354. doi: 10.1146/annurev.pharmtox.010909.105600

87. Lai C, Loo G. Cellular iron depletion weakens induction of heme oxygenase-1 by cadmium. Int J Biochem Cell Biol. (2011) 43:8897. doi: 10.1016/j.biocel.2010.09.025

88. Correia MA, Sinclair PR, De Matteis F. Cytochrome P450 regulation: the interplay between its heme and apoprotein moieties in synthesis, assembly, repair, and disposal. Drug Metab Rev. (2011) 43:1-26. doi: 10.3109/03602532.2010.515222

89. Lin HL, Zhang H, Walker VJ, D'Agostino J, Hollenberg PF. Heme modification contributes to the mechanism-based inactivation of human cytochrome P450 2J2 by two terminal acetylenic compounds. Drug Metab Dispos. (2017) 45:990-9. doi: 10.1124/dmd.117.075846

90. Zhu Y, Silverman RB. Revisiting heme mechanisms. A perspective on the mechanisms of nitric oxide synthase (NOS), Heme oxygenase (HO), and cytochrome P450s (CYP450s). Biochemistry. (2008) 47:223143. doi: 10.1021/bi7023817

91. Dhur A, Galan P, Hercberg S. Effects of different degrees of iron deficiency on cytochrome $\mathrm{P} 450$ complex and pentose phosphate pathway dehydrogenases in the rat. J Nutr. (1989) 119:40-7. doi: 10.1093/jn/119.1.40

92. Rao NJ, Jagadeesan V. Effect of long term iron deficiency on the activities of hepatic and extra-hepatic drug metabolising enzymes in Fischer rats. Comp Biochem Physiol B Biochem Mol Biol. (1995) 110:16773. doi: 10.1016/0305-0491(94)00109-8

93. Yang $\mathrm{C}$, Li $\mathrm{C}$, Li $\mathrm{M}$, Tong $\mathrm{X}, \mathrm{Hu} \mathrm{X}$, Yang $\mathrm{X}$, et al. CYP2S1 depletion enhances colorectal cell proliferation is associated with PGE2mediated activation of $\beta$-catenin signaling. Exp Cell Res. (2015) 331:37786. doi: 10.1016/j.yexcr.2014.12.008

94. Atamna H, Killilea DW, Killilea AN, Ames BN. Heme deficiency may be a factor in the mitochondrial and neuronal decay of aging. Proc Natl Acad Sci USA. (2002) 99:14807-12. doi: 10.1073/pnas.192585799

95. Wallace DC. A mitochondrial paradigm of metabolic and degenerative diseases, aging, and cancer: a dawn for evolutionary medicine. Annu Rev Genet. (2005) 39:359-407. doi: 10.1146/annurev.genet.39.110304.095751

96. Inoue $\mathrm{H}$, Hanawa $\mathrm{N}$, Katsumata SI, Katsumata-Tsuboi $\mathrm{R}$, Takahashi $\mathrm{N}$, Uehara M. Iron deficiency induces autophagy and activates Nrf2 signal through modulating p62/SQSTM. Biomed Res. (2017) 38:34350. doi: 10.2220/biomedres.38.343

97. Merikallio H, Pääkkö P, Kinnula VL, Harju T, Soini Y. Nuclear factor erythroid-derived 2-like 2 (Nrf2) and DJ1 are prognostic factors in lung cancer. Hum Pathol. (2012) 43:577-84. doi: 10.1016/j.humpath.2011.05.024

98. Solis LM, Behrens C, Dong W, Suraokar M, Ozburn NC, Moran CA, et al. Nrf2 and Keap1 abnormalities in non-small cell lung carcinoma and association with clinicopathologic features. Clin Cancer Res. (2010) 16:374353. doi: 10.1158/1078-0432.CCR-09-3352

99. Lau A, Villeneuve NF, Sun Z, Wong PK, Zhang DD. Dual roles of Nrf2 in cancer. Pharmacol Res. (2008) 58:262-70. doi: 10.1016/j.phrs.2008.09.003

100. Menegon S, Columbano A, Giordano S. The dual roles of NRF2 in cancer. Trends Mol Med. (2016) 22:578-93. doi: 10.1016/j.molmed.2016.05.002

101. Leinonen HM, Kansanen E, Pölönen P, Heinäniemi M, Levonen AL. Role of the Keap1-Nrf2 pathway in cancer. Adv Cancer Res. (2014) 122:281320. doi: 10.1016/B978-0-12-420117-0.00008-6
102. Hanahan D, Weinberg RA. Hallmarks of cancer: the next generation. Cell. (2011) 144:646-74. doi: 10.1016/j.cell.2011.02.013

103. D'Ignazio L, Bandarra D, Rocha S. NF- $\kappa B$ and HIF crosstalk in immune responses. FEBS J. (2016) 283:413-24. doi: 10.1111/febs.13578

104. Meteoglu I, Erdogdu IH, Meydan N, Erkus M, Barutca S. NFKappaB expression correlates with apoptosis and angiogenesis in clear cell renal cell carcinoma tissues. J Exp Clin Cancer Res. (2008) 27:53. doi: 10.1186/1756-9966-27-53

105. Wang L, Cherayil BJ. Ironing out the wrinkles in host defense: interactions between iron homeostasis and innate immunity. J Innate Immun. (2009) 1:455-64. doi: 10.1159/000210016

106. Schito L, Semenza GL. Hypoxia-inducible factors: master regulators of cancer progression. Trends Cancer. (2016) 2:75870. doi: 10.1016/j.trecan.2016.10.016

107. Deeb G, Vaughan MM, McInnis I, Ford LA, Sait SN, Starostik P, et al. Hypoxia-inducible factor- $1 \alpha$ protein expression is associated with poor survival in normal karyotype adult acute myeloid leukemia. Leuk Res. (2011) 35:579-84. doi: 10.1016/j.leukres.2010.10.020

108. Harrison LB, Chadha $\mathrm{M}$, Hill RJ, Hu K, Shasha D. Impact of tumor hypoxia and anemia on radiation therapy outcomes. Oncologist. (2002) 7:492-508. doi: 10.1634/theoncologist.7-6-492

109. Vaupel P, Harrison L. Tumor hypoxia: causative factors, compensatory mechanisms, and cellular response. Oncologist. (2004) 9 (Suppl. 5):49. doi: 10.1634/theoncologist.9-90005-4

110. Ryan HE, Poloni M, McNulty W, Elson D, Gassmann M, Arbeit JM, et al. Hypoxia-inducible factor-1alpha is a positive factor in solid tumor growth. Cancer Res. (2000) 60:4010-5.

111. Elson DA, Ryan HE, Snow JW, Johnson R, Arbeit JM. Coordinate upregulation of hypoxia inducible factor (HIF)-1alpha and HIF-1 target genes during multi-stage epidermal carcinogenesis and wound healing. Cancer Res. (2000) 60:6189-95.

112. Dongiovanni P, Valenti L, Ludovica Fracanzani A, Gatti S, Cairo G, Fargion S. Iron depletion by deferoxamine up-regulates glucose uptake and insulin signaling in hepatoma cells and in rat liver. Am J Pathol. (2008) 172:73847. doi: 10.2353/ajpath.2008.070097

113. Eckard J, Dai J, Wu J, Jian J, Yang Q, Chen H, et al. Effects of cellular iron deficiency on the formation of vascular endothelial growth factor and angiogenesis. Cancer Cell Int. (2010) 10:28. doi: 10.1186/1475-2867-10-28

114. Jacobsen J, Grankvist K, Rasmuson T, Bergh A, Landberg G, Ljungberg B. Expression of vascular endothelial growth factor protein in human renal cell carcinoma. BJU Int. (2004) 93:297-302. doi: 10.1111/j.1464-410X.2004.04605.x

115. Paino IM, Miranda JC, Marzocchi-Machado CM, Cesarino EJ, de Castro FA, de Souza AM. Phagocytosis, oxidative burst, and produced reactive species are affected by iron deficiency anemia and anemia of chronic diseases in elderly. Biol Trace Elem Res. (2009) 129:11625. doi: 10.1007/s12011-008-8303-8

116. Winterbourn CC, Kettle AJ, Hampton MB. Reactive oxygen species and neutrophil function. Annu Rev Biochem. (2016) 85:765-92. doi: 10.1146/annurev-biochem-060815-014442

117. Yamaguchi R, Kawata J, Yamamoto T, Ishimaru Y, Sakamoto A, Ono T, et al. Mechanism of interferon-gamma production by monocytes stimulated with myeloperoxidase and neutrophil extracellular traps. Blood Cells Mol Dis. (2015) 55:127-33. doi: 10.1016/j.bcmd.2015.05.012

118. Bergman M, Salman H, Pinchasi R, Straussberg R, Djaldetti M, Bessler H. Phagocytic capacity and apoptosis of peripheral blood cells from patients with iron deficiency anemia. Biomed Pharmacother. (2005) 59:30711. doi: 10.1016/j.biopha.2004.11.009

119. Moretta L, Montaldo E, Vacca P, Del Zotto G, Moretta F, Merli P, et al. Human natural killer cells: origin, receptors, function, and clinical applications. Int Arch Allergy Immunol. (2014) 164:253-64. doi: 10.1159/000365632

120. Balsamo M, Manzini C, Pietra G, Raggi F, Blengio F, Mingari MC, et al. Hypoxia downregulates the expression of activating receptors involved in NK-cell-mediated target cell killing without affecting ADCC. Eur J Immunol. (2013) 43:2756-64. doi: 10.1002/eji.201343448

121. Schilling D, Tetzlaff F, Konrad S, Li W, Multhoff G. A hypoxia-induced decrease of either MICA/B or Hsp70 on the membrane of tumor cells 
mediates immune escape from NK cells. Cell Stress Chaperones. (2015) 20:139-47. doi: 10.1007/s12192-014-0532-5

122. Bowlus CL. The role of iron in T cell development and autoimmunity. Autoimmun Rev. (2003) 2:73-8. doi: 10.1016/S1568-9972(02)00143-X

123. Kuvibidila SR, Porretta C, Surendra Baliga B, Leiva LE. Reduced thymocyte proliferation but not increased apoptosis as a possible cause of thymus atrophy in iron-deficient mice. Br J Nutr. (2001) 86:15762. doi: 10.1079/BJN2001366

124. Kuvibidila SR, Porretta C. Iron deficiency and in vitro iron chelation reduce the expression of cluster of differentiation molecule (CD)28 but not CD3 receptors on murine thymocytes and spleen cells. Br J Nutr. (2003) 90:17989. doi: 10.1079/BJN2003864

125. Kuvibidila SR, Kitchens D, Baliga BS. In vivo and in vitro iron deficiency reduces protein kinase $\mathrm{C}$ activity and translocation in murine splenic and purified T cells. J Cell Biochem. (1999) 74:468-78. doi: 10.1002/(SICI)10974644(19990901) 74:3<468::AID-JCB14>3.0.CO;2-G

126. Klecha AJ, Salgueiro J, Wald M, Boccio J, Zubillaga M, Leonardi $\mathrm{NM}$, et al. In vivo iron and zinc deficiency diminished T- and Bselective mitogen stimulation of murine lymphoid cells through protein kinase C-mediated mechanism. Biol Trace Elem Res. (2005) 104:17383. doi: 10.1385/BTER:104:2:173

127. Kuvibidila S, Warrier RP. Differential effects of iron deficiency and underfeeding on serum levels of interleukin-10, interleukin12p40, and interferon-gamma in mice. Cytokine. (2004) 26:73-81. doi: 10.1016/j.cyto.2003.12.010

128. Kuvibidila S, Yu L, Ode D, Velez M, Gardner R, Warrier RP. Effects of iron deficiency on the secretion of interleukin-10 by mitogen-activated and non-activated murine spleen cells. J Cell Biochem. (2003) 90:27886. doi: $10.1002 /$ jcb. 10627

129. Kuvibidila SR, Velez M, Gardner R, Penugonda K, Chandra LC, Yu L. Iron deficiency reduces serum and in vitro secretion of interleukin- 4 in mice independent of altered spleen cell proliferation. Nutr Res. (2012) 32:10715. doi: 10.1016/j.nutres.2011.12.005

130. Longpre J, Loo G. Inhibition of deoxycholate-induced apoptosis in iron-depleted HCT-116 cells. Apoptosis. (2012) 17:708. doi: 10.1007/s10495-011-0655-4

131. de Deungria M, Rao R, Wobken JD, Luciana M, Nelson CA, Georgieff MK. Perinatal iron deficiency decreases cytochrome $c$ oxidase (CytOx) activity in selected regions of neonatal rat brain. Pediatr Res. (2000) 48:16976. doi: 10.1203/00006450-200008000-00009

132. Payne CM, Holubec H, Bernstein C, Bernstein H, Dvorak K, Green $\mathrm{SB}$, et al. Crypt-restricted loss and decreased protein expression of cytochrome $\mathrm{C}$ oxidase subunit I as potential hypothesis-driven biomarkers of colon cancer risk. Cancer Epidemiol Biomarkers Prev. (2005) 14:206675. doi: 10.1158/1055-9965.EPI-05-0180

133. Herrinton LJ, Friedman GD, Baer D, Selby JV. Transferrin saturation and risk of cancer. Am J Epidemiol. (1995) 142:6928. doi: 10.1093/oxfordjournals.aje.a117698

134. Kato I, Dnistrian AM, Schwartz M, Toniolo P, Koenig K, Shore RE, et al. Iron intake, body iron stores and colorectal cancer risk in women: a nested case-control study. Int J Cancer. (1999) 80:6938. doi: 10.1002/(SICI)1097-0215(19990301)80:5<693::AID-IJC11 > 3.0.CO;2G

135. Bird CL, Witte JS, Swendseid ME, Shikany JM, Hunt IF, Frankl HD, et al. Plasma ferritin, iron intake, and the risk of colorectal polyps. Am J Epidemiol. (1996) 144:34-41. doi: 10.1093/oxfordjournals.aje.a008852

136. Cross AJ, Gunter MJ, Wood RJ, Pietinen P, Taylor PR, Virtamo J, et al. Iron and colorectal cancer risk in the alpha-tocopherol, beta-carotene cancer prevention study. Int J Cancer. (2006) 118:3147-52. doi: 10.1002/ijc.21780

137. Hamarneh Z, Symonds EL, Kholmurodova F, Cock C. Older age, symptoms, or anemia: Which factors increase colorectal cancer risk with a positive fecal immunochemical test? J Gastroenterol Hepatol. (2020) 35:10028. doi: $10.1111 /$ jgh. 14888

138. Zhen L, Zhe S, Zhenning W, Zhifeng M, Zhidong L, Xiaoxia L, et al. Iron-deficiency anemia: a predictor of diminished disease-free survival of T3N0M0 stage colon cancer. J Surg Oncol. (2012) 105:3715. doi: $10.1002 /$ jso. 22032
139. Prá D, Rech Franke SI, Pegas Henriques JA, Fenech M. A possible link between iron deficiency and gastrointestinal carcinogenesis. Nutr Cancer. (2009) 61:415-26. doi: 10.1080/01635580902 803701

140. Lorenzi M, Lorenzi B, Vernillo R. Serum ferritin in colorectal cancer patients and its prognostic evaluation. Int J Biol Markers. (2006) 21:23541. doi: $10.1177 / 172460080602100407$

141. An MS, Yoo JH, Kim KH, Bae KB, Choi CS, Hwang JW, et al. T4 stage and preoperative anemia as prognostic factors for the patients with colon cancer treated with adjuvant FOLFOX chemotherapy. World J Surg Oncol. (2015) 13:64. doi: 10.1186/s12957-015-0488-7

142. Acheson AG, Brookes MJ, Spahn DR. Effects of allogeneic red blood cell transfusions on clinical outcomes in patients undergoing colorectal cancer surgery: a systematic review and meta-analysis. Ann Surg. (2012) 256:23544. doi: 10.1097/SLA.0b013e31825b35d5

143. Amato A, Pescatori M. Perioperative blood transfusions for the recurrence of colorectal cancer. Cochrane Database Syst Rev. (2006) 2006:CD005033. doi: 10.1002/14651858.CD005033.pub2

144. Pascual M, Bohle B, Alonso S, Mayol X, Salvans S, Grande L, et al. Preoperative administration of erythropoietin stimulates tumor recurrence after surgical excision of colon cancer in mice by a vascular endothelial growth factor-independent mechanism. J Surg Res. (2013) 183:2707. doi: 10.1016/j.jss.2012.12.041

145. Henry DH, Dahl NV, Auerbach M, Tchekmedyian S, Laufman LR. Intravenous ferric gluconate significantly improves response to epoetin alfa versus oral iron or no iron in anemic patients with cancer receiving chemotherapy. Oncologist. (2007) 12:23142. doi: 10.1634/theoncologist.12-2-231

146. Petrelli F, Borgonovo K, Cabiddu M, Lonati V, Barni S. Addition of iron to erythropoiesis-stimulating agents in cancer patients: a metaanalysis of randomized trials. J Cancer Res Clin Oncol. (2012) 138:17987. doi: $10.1007 / \mathrm{s} 00432-011-1072-3$

147. Gafter-Gvili A, Rozen-Zvi B, Vidal L, Leibovici L, Vansteenkiste J, Gafter $\mathrm{U}$, et al. Intravenous iron supplementation for the treatment of chemotherapy-induced anaemia - systematic review and meta-analysis of randomised controlled trials. Acta Oncol. (2013) 52:18-29. doi: 10.3109/0284186X.2012.702921

148. Phipps O, Al-Hassi HO, Quraishi MN, Kumar A, Brookes MJ. Influence of iron on the gut microbiota in colorectal cancer. Nutrients. (2020) 12:2512. doi: $10.3390 /$ nu12092512

149. Ludwig H, Evstatiev R, Kornek G, Aapro M, Bauernhofer T, Buxhofer-Ausch $\mathrm{V}$, et al. Iron metabolism and iron supplementation in cancer patients. Wien Klin Wochenschr. (2015) 127:907-19. doi: 10.1007/s00508-015-0842-3

150. Dangsuwan P, Manchana T. Blood transfusion reduction with intravenous iron in gynecologic cancer patients receiving chemotherapy. Gynecol Oncol. (2010) 116:522-5. doi: 10.1016/j.ygyno.2009.12.004

151. Hedenus M, Karlsson T, Ludwig H, Rzychon B, Felder M, Roubert B, et al. Intravenous iron alone resolves anemia in patients with functional iron deficiency and lymphoid malignancies undergoing chemotherapy. Med Oncol. (2014) 31:302. doi: 10.1007/s12032-014-0302-3

152. Steinmetz T, Tschechne B, Harlin O, Klement B, Franzem M, Wamhoff J, et al. Clinical experience with ferric carboxymaltose in the treatment of cancer- and chemotherapy-associated anaemia. Ann Oncol. (2013) 24:47582. doi: $10.1093 /$ annonc/mds338

153. Kim YT, Kim SW, Yoon BS, Cho HJ, Nahm EJ, Kim SH, et al. Effect of intravenously administered iron sucrose on the prevention of anemia in the cervical cancer patients treated with concurrent chemoradiotherapy. Gynecol Oncol. (2007) 105:199-204. doi: 10.1016/j.ygyno.2006.11.014

154. Abdel-Razeq H, Abbasi S, Saadi I, Jaber R, Abdelelah H. Intravenous iron monotherapy for the treatment of non-iron-deficiency anemia in cancer patients undergoing chemotherapy: a pilot study. Drug Des Dev Ther. (2013) 7:939-44. doi: 10.2147/DDDT.S45674

155. Birgegård G, Henry D, Glaspy J, Chopra R, Thomsen LL, Auerbach M. A randomized noninferiority trial of intravenous iron isomaltoside versus oral iron sulfate in patients with nonmyeloid malignancies and anemia receiving chemotherapy: the PROFOUND trial. Pharmacotherapy. (2016) 36:402-14. doi: 10.1002/phar.1729 
156. Vadhan-Raj S, Dahl NV, Bernard K, Li Z, Strauss WE. Efficacy and safety of IV ferumoxytol for iron deficiency anemia in patients with cancer. J Blood Med. (2017) 8:199-209. doi: 10.2147/JBM.S138474

157. Verhaeghe L, Bruyneel L, Stragier E, Ferrante M, Dierickx D, Prenen $H$. The effectiveness of intravenous iron for iron deficiency anemia in gastrointestinal cancer patients: a retrospective study. Ann Gastroenterol. (2017) 30:654-63. doi: 10.20524/aog.2017.0189

158. Keeler BD, Simpson JA, Ng S, Tselepis C, Iqbal T, Brookes MJ, et al. The feasibility and clinical efficacy of intravenous iron administration for preoperative anaemia in patients with colorectal cancer. Colorectal Dis. (2014) 16:794-800. doi: 10.1111/codi.12683

159. Calleja JL, Delgado S, del Val A, Hervás A, Larraona JL, Terán Á, et al. Ferric carboxymaltose reduces transfusions and hospital stay in patients with colon cancer and anemia. Int J Colorectal Dis. (2016) 31:54351. doi: 10.1007/s00384-015-2461-x

160. Kam PM, Chu CW, Chan EM, Liu OL, Kwok KH. Use of intravenous iron therapy in colorectal cancer patient with iron deficiency anemia: a propensity-score matched study. Int J Colorectal Dis. (2020) 35:5217. doi: 10.1007/s00384-020-03508-y

161. Borstlap WA, Stellingwerf ME, Moolla Z, Musters GD, Buskens CJ, Tanis PJ, et al. Iron therapy for the treatment of preoperative anaemia in patients with colorectal carcinoma: a systematic review. Colorectal Dis. (2015) 17:104454. doi: 10.1111/codi.13110

162. Keeler BD, Simpson JA, Ng O, Padmanabhan H, Brookes MJ, Acheson AG. Randomized clinical trial of preoperative oral versus intravenous iron in anaemic patients with colorectal cancer. Br J Surg. (2017) 104:21421. doi: $10.1002 /$ bjs. 10328

163. Laso-Morales M, Jericó C, Gómez-Ramírez S, Castellví J, Viso L, RoigMartínez I, et al. Preoperative management of colorectal cancer-induced iron deficiency anemia in clinical practice: data from a large observational cohort. Transfusion. (2017) 57:3040-8. doi: 10.1111/trf.14278

164. Dickson EA, Keeler BD, Ng O, Kumar A, Brookes MJ, Acheson AG, et al. Preoperative intravenous iron therapy and survival after colorectal cancer surgery: long-term results from the IVICA randomised controlled trial. Colorectal Dis. (2020) 22:2018-27. doi: 10.1111/codi.15342

165. Torti SV, Torti FM. Iron and cancer: more ore to be mined. Nat Rev Cancer. (2013) 13:342-55. doi: 10.1038/nrc3495

166. Manz DH, Blanchette NL, Paul BT, Torti FM, Torti SV. Iron and cancer: recent insights. Ann N Y Acad Sci. (2016) 1368:149-61. doi: 10.1111/nyas.13008

167. Gilreath JA, Stenehjem DD, Rodgers GM. Total dose iron dextran infusion in cancer patients: is it SaFe2+? J Nat Compr Canc Netw. (2012) 10:669-76. doi: 10.6004/jnccn.2012.0066

168. Wilson MJ, Harlaar JJ, Jeekel J, Schipperus M, Zwaginga JJ. Iron therapy as treatment of anemia: a potentially detrimental and hazardous strategy in colorectal cancer patients. Med Hypotheses. (2018) 110:1103. doi: 10.1016/j.mehy.2017.12.011

169. Beguin Y, Aapro M, Ludwig H, Mizzen L, Osterborg A. Epidemiological and nonclinical studies investigating effects of iron in carcinogenesis-a critical review. Crit Rev Oncol Hematol. (2014) 89:1-15. doi: 10.1016/j.critrevonc.2013.10.008

170. Seril DN, Liao J, Ho KL, Warsi A, Yang CS, Yang GY. Dietary iron supplementation enhances DSS-induced colitis and associated colorectal carcinoma development in mice. Digest Dis Sci. (2002) 47:1266-78. doi: 10.1023/A:1015362228659

171. Ilsley JN, Belinsky GS, Guda K, Zhang Q, Huang X, Blumberg JB, et al. Dietary iron promotes azoxymethane-induced colon tumors in mice. Nutr Cancer. (2004) 49:162-9. doi: 10.1207/s15327914nc4902_7
172. Seril DN, Liao J, Yang CS, Yang GY. Systemic iron supplementation replenishes iron stores without enhancing colon carcinogenesis in murine models of ulcerative colitis: comparison with iron-enriched diet. Digest Dis Sci. (2005) 50:696-707. doi: 10.1007/s10620-005-2560-6

173. Chua AC, Klopcic B, Lawrance IC, Olynyk JK, Trinder D. Iron: an emerging factor in colorectal carcinogenesis. World J Gastroenterol. (2010) 16:66372. doi: 10.3748/wjg.v16.i6.663

174. Radulescu S, Brookes MJ, Salgueiro P, Ridgway RA, McGhee E, Anderson $\mathrm{K}$, et al. Luminal iron levels govern intestinal tumorigenesis after Apc loss in vivo. Cell Rep. (2016) 17:2805-7. doi: 10.1016/j.celrep.2016. 10.028

175. Jaspers A, Baron F, Servais S, Lejeune M, Willems É, Seidel L, et al. Erythropoietin therapy after allogeneic hematopoietic cell transplantation has no impact on long-term survival. Am J Hematol. (2015) 90:E1979. doi: 10.1002/ajh.24100

176. Wilson MJ, Dekker JWT, Buettner S, Harlaar JJ, Jeekel J, Schipperus M, et al. The effect of intravenous iron therapy on long-term survival in anaemic colorectal cancer patients: Results from a matched cohort study. Surg Oncol. (2018) 27:192-9. doi: 10.1016/j.suronc.2018.03.005

177. Nairz M, Dichtl S, Schroll A, Haschka D, Tymoszuk P, Theurl I, et al. Iron and innate antimicrobial immunity-depriving the pathogen, defending the host. J Trace Elem Med Biol. (2018) 48:118-33. doi: 10.1016/j.jtemb.2018.03.007

178. Auerbach M, Silberstein PT, Webb RT, Averyanova S, Ciuleanu TE, Shao J, et al. Darbepoetin alfa 300 or $500 \mu \mathrm{g}$ once every 3 weeks with or without intravenous iron in patients with chemotherapy-induced anemia. Am J Hematol. (2010) 85:655-63. doi: 10.1002/ajh.21779

179. Bastit L, Vandebroek A, Altintas S, Gaede B, Pintér T, Suto TS, et al. Randomized, multicenter, controlled trial comparing the efficacy and safety of darbepoetin alpha administered every 3 weeks with or without intravenous iron in patients with chemotherapy-induced anemia. J Clin Oncol. (2008) 26:1611-8. doi: 10.1200/JCO.2006.10.4620

180. Hedenus M, Birgegård G, Näsman P, Ahlberg L, Karlsson T, Lauri B, et al. Addition of intravenous iron to epoetin beta increases hemoglobin response and decreases epoetin dose requirement in anemic patients with lymphoproliferative malignancies: a randomized multicenter study. Leukemia. (2007) 21:627-32. doi: 10.1038/sj.leu.2404562

Conflict of Interest: AA: Congress expenses, consultancy and lecturing fees: Vifor Pharma and Immundiagnostik AG. KF: Speakers' honoraria: Immundiagnostik AG. OS: Congress expenses: Abbvie, Falk, Janssen, Takeda; Lecturing fees: Abbvie, Falk, Janssen, Takeda, Norgine, Pfizer. JS: Consulting: Pharmacosmos, Vifor. Abbvie, Bristol Myers Squibb, Dr Schär, Falk, Ferring, Fresenius Kabi, Immundiagnostik, Janssen, Medice, MSD, Pfizer, Shire, Takeda, Thermofisher. Board member: Pharmacosmos, Vifor, Abbvie, Bristol Myers Squibb, Dr Schär, Ferring, Fresenius Kabi, Immundiagnostik, Janssen, MSD, NPS, Takeda, Shield. Lecturing: Vifor.

The remaining authors declare that the research was conducted in the absence of any commercial or financial relationships that could be construed as a potential conflict of interest.

Copyright (C) 2021 Aksan, Farrag, Aksan, Schroeder and Stein. This is an open-access article distributed under the terms of the Creative Commons Attribution License (CC $B Y)$. The use, distribution or reproduction in other forums is permitted, provided the original author(s) and the copyright owner(s) are credited and that the original publication in this journal is cited, in accordance with accepted academic practice. No use, distribution or reproduction is permitted which does not comply with these terms. 